\title{
EYE SIGHT DETERMINATION ON TABLET BASED HAND HELD DEVICE WITH IMAGE PROCESSING TECHNIQUES THAT MINIMIZES ERROR WITH IMPROVED PATIENT INTERACTION
}

\author{
V. Punna Rao ${ }^{1}$, T. Adilakshmi ${ }^{2}$, Anurag Pradan ${ }^{3}$ \\ ${ }^{I}$ Department of computer science, Vasavi College of Engineering, Hyderabad, India \\ ${ }^{2}$ Department of computer science, Vasavi College of Engineering, Hyderabad, India \\ ${ }^{3}$ Department of computer science, Vasavi College of Engineering, Hyderabad, India
}

\begin{abstract}
The main aim of this work is to increase the accuracy in finding out the acuity errors in the human eye. The scope of the proposed system is to overcome the minute errors in finding the acuity errors in the eye and to specify the accurate sight of patient by the doctors.

The objective of this project is to design application for handheld device which calculates the human eye sight. This project is done by Digital Image processing techniques in a practical approach, which would help us to compute the accurate readings.
\end{abstract}

Keywords: Eye sight determination, Image processing, patient interactive, and tablet PC ***

\section{INTRODUCTION}

Human acuity error occurs because of unexpected focal point(s) in the human eye. If the focal point falls before retina then it is called myopia or short sight and if the focal point falls beyond retina, then it is called Hyperopia or long sight. These are usually corrected by using contact lens or spectacles. Doctor uses retinoscopic mirror to detect the type of disease. Earlier, they use to keep the snellen charts at a distance from patient and keep on asking the contents of the charts.

Patient's interaction is found to be less which may result in errors while assigning power to the spectacles.

To test the eye sight of the patient in the present system, we have manual testing and computerized eye testing. To make sure that the error is accurate, after the doctor determines the eye sight of the patient using the trial lens, he is given a tablet PC device which displays the blurred images, then the patient selects the blurred image that looks similar to that when he have seen the image in the projector. Based on the image selected the accurate acuity error of the patient is determined by the doctor.

\section{PROPOSED METHODOLOGY}

To test the eye sight of the patient in the present system, we have manual testing and computerized eye testing. To make sure that the error is accurate, after the doctor determines the eye sight of the patient using the trial lens, he is given a tablet PC device which displays the blurred images, then the patient selects the blurred image that looks similar to that when he have seen the image in the projector. Based on the image selected the accurate acuity error of the patient is determined by the doctor.

In this project we are using SNELLEN CHART to determine the eye sight. This chart is the common and standard chart which is used for testing of human acuity. The Snellen chart contains English letters at different sizes, where the patient should be able to recognize them at different level of size.

The given specifications for us regarding the Snellen chart is shown below

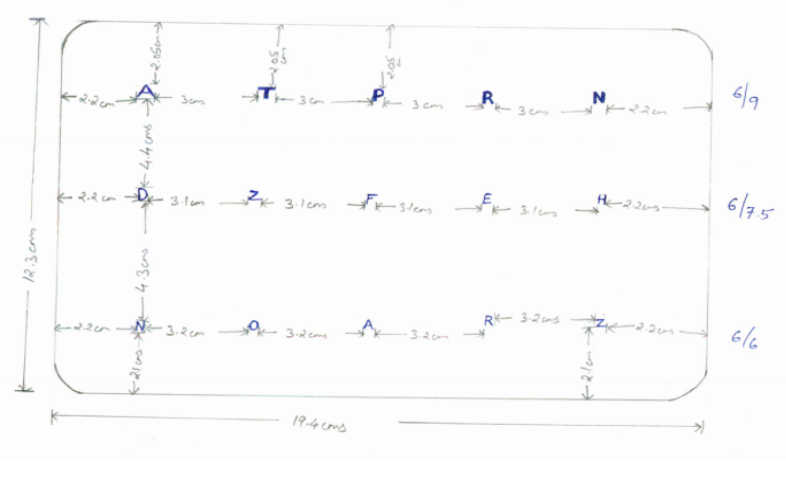

Fig 2.1: Chart Specification 


\subsection{Defects of Eye}

An eye examination is a battery of tests performed by an ophthalmologist, optometrist, assessing vision and ability to focus on and discern objects, as well as other tests and examinations pertaining to the eyes. Health care professionals often recommend that all people should have periodic and thorough eye examinations as part of routine primary care, especially since many eye diseases are asymptomatic. Eye examinations may detect potentially treatable blinding eye diseases, ocular manifestations of systemic disease, or signs of tumors or other anomalies of the brain.

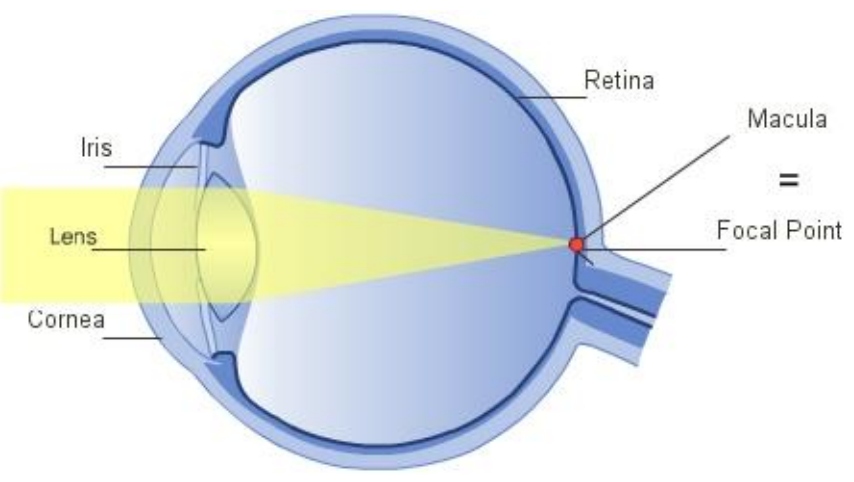

Fig 2.2: Formation of image in the Eye

\subsubsection{Myopia (nearsightedness)}

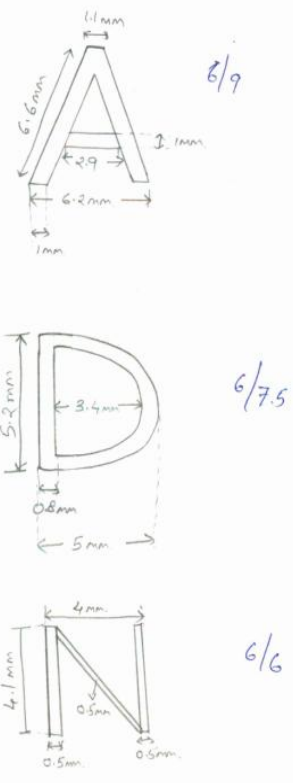

Fig 2.3: Myopia
This is a defect of vision in which far objects appear blurred but near objects are seen clearly. The image is focused in front of the retina rather than on it usually because the eyeball is too long or the refractive power of the eye's lens too strong. Myopia can be corrected by wearing glasses/contacts with concave lenses these help to focus the image on the retina.
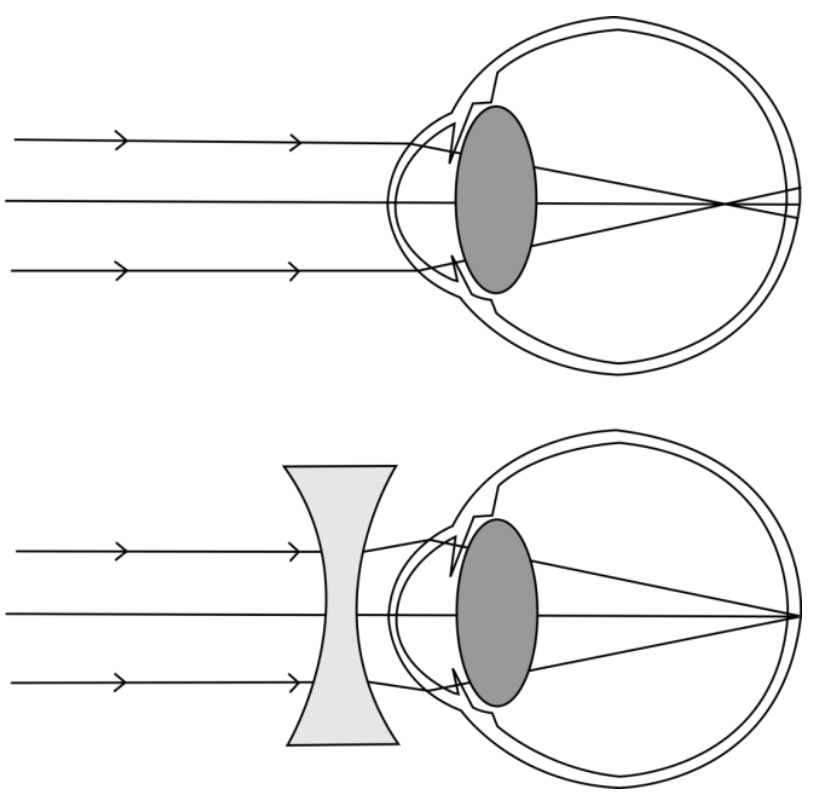

Myopia

\subsubsection{Hyperopia (farsightedness)}
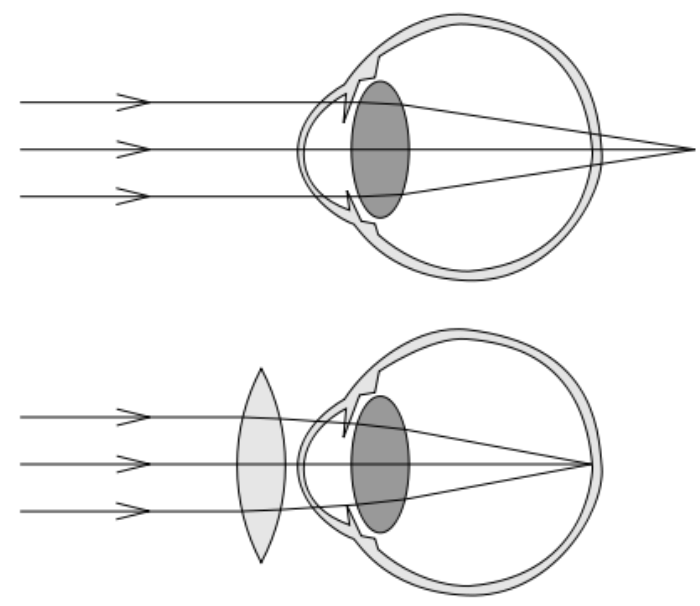

Fig 2.4: Hyperopia

This is a defect of vision in which there is difficulty with near vision but far objects can be seen easily. The image is focused behind the retina rather than upon it. This occurs when the eyeball is too short or the refractive power of the lens is too 
weak. Hyperopia can be corrected by wearing glasses/contacts that contain convex lenses.

\subsubsection{Astigmatism}

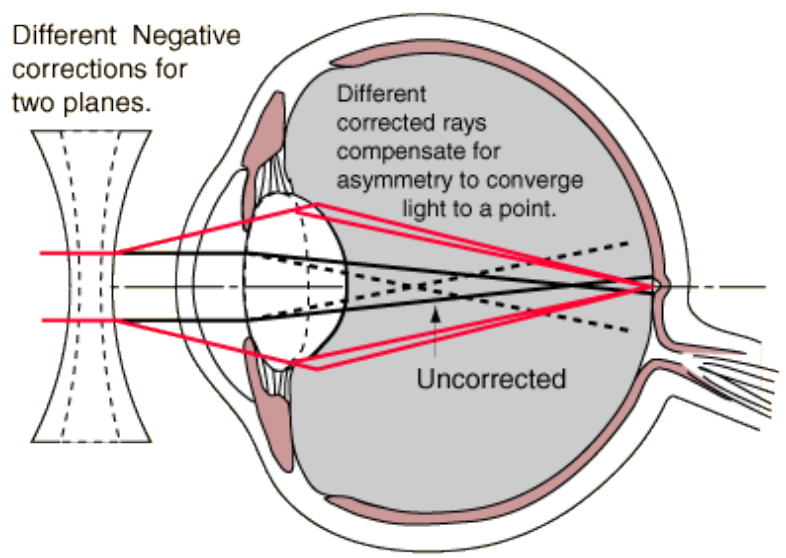

Fig 2.5: Astigmatism

This defect is when the light rays do not all come to a single focal point on the retina, instead some focus on the retina and some focus in front of or behind it. This is usually caused by a non-uniform curvature of the cornea. A typical symptom of astigmatism is if you are looking at a pattern of lines placed at various angles and the lines running in one direction

appear sharp whilst those in other directions appear blurred. Astigmatism can usually be corrected by using a special spherical cylindrical lens; this is placed in the out-of-focus axis.

In case of astigmatism some rays focuses in front of retina and some focuses beyond retina
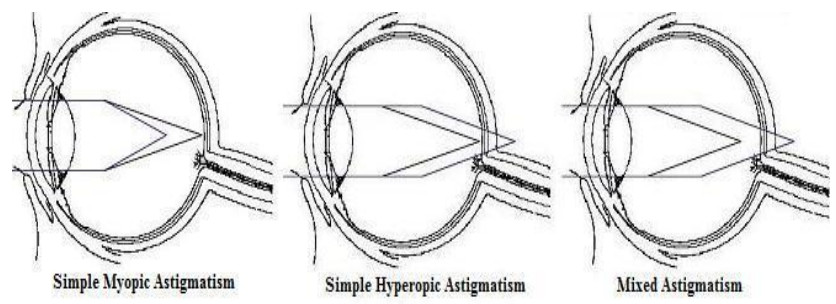

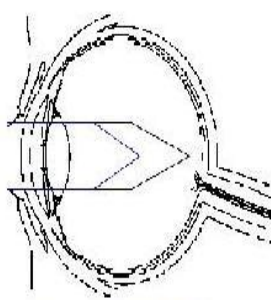

Compound Myopic Astigmatism

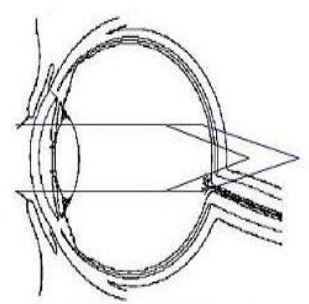

Compound Hyperopic Astigmatism
Fig 2.6: Different forms of Astigmatism
3. CHARTS CREATION

AND

\section{IMPLEMENTATION}

\subsection{Snellen Chart Created according to the given} Specification

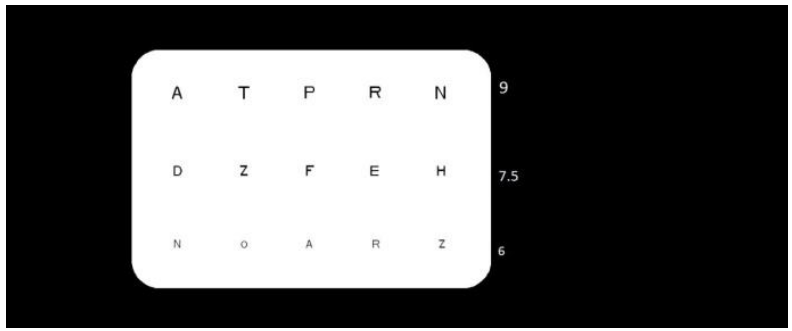

Fig 3.1: Snellen Chart with given specification

Snellen chart created according to the specification

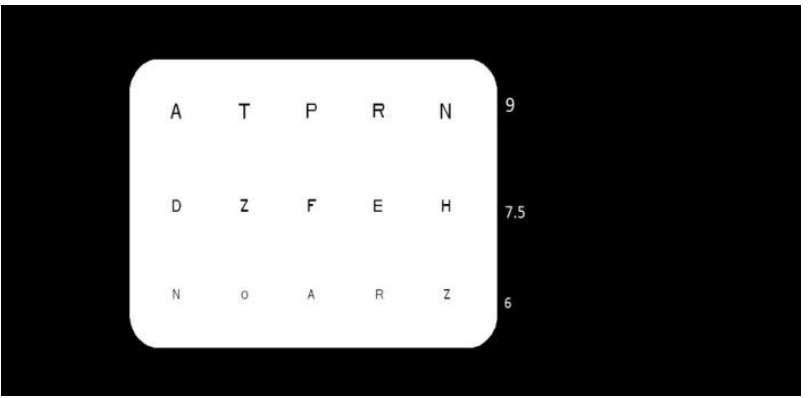

Fig 3.1: Snellen Chart with given specification

\subsection{Implementation of Filters}

In image processing, 2D filtering techniques are usually considered an extension of 1D signal processing theory. Almost all contemporary image processing involves discrete or sampled signal processing. This is compared to signal processing that was applied to analog or continuous time domain processing that characterized television and video several generations ago. The two are related, and the foundation for discrete signal processing is derived from continuous time signal processing theory.

A low-pass filter passes low-frequency signals and attenuates signals with frequencies higher than the cut off frequency.

In this project we implemented low pass filters of the digital image processing. Low-pass filtering smoothes an image. Low pass filtering, otherwise known as "smoothing", is employed to remove high spatial frequency noise from a digital image. There are mainly 3 types of low pass filters.

- Ideal low pass filter

- Butterworth low pass filter

- Gaussian low pass filter 
The 2-D discrete Fourier transform:-

The discrete Fourier transform of a image $f(x, y)$ of size $M^{*} N$ is given by the equation

$$
F(u, v)=\frac{1}{M N} \sum_{x=0}^{M-1} \cdot \sum_{y=0}^{N-1} f(x, y) e^{-j 2 \pi\left(\frac{u x}{M}+\frac{v y}{N}\right)}
$$

Similarly given $\mathrm{F}(\mathrm{u}, \mathrm{v})$ we obtain $\mathrm{f}(\mathrm{x}, \mathrm{y})$ via the inverse discrete Fourier transform given by the expression

$\mathrm{f}(\mathrm{x}, \mathrm{y})=$

$$
\sum_{x=0}^{M-1} \cdot \sum_{y=0}^{N-1} F(u, v) e^{-j 2 \pi\left(\frac{u x}{M}+\frac{v y}{N}\right)}
$$

\subsubsection{Implementation of Ideal Low pass filter:}

A 2D lowpass filter that passes without attenuation all frequencies within a circle of radius $\mathrm{D}_{0}$ from the origin and "cuts off" all frequencies outside this circle is called an ideal lowpass filter (ILPF); it is specified by the function

$$
H(u, v)=\left\{\begin{array}{l}
1 \text { if } D(u, v) \leq D_{0} \\
0 \text { if } D(u, v)>D_{0}
\end{array}\right.
$$

Where $\mathrm{D}_{0}$ is a positive constant and $\mathrm{D}(\mathrm{u}, \mathrm{v})$ is the distance between the point $(\mathrm{u}, \mathrm{v})$ in the frequency domain and the centre of the frequency rectangle.

\subsubsection{Gaussian Low Pass Filter:}

The transfer function for Gaussian lowpass filter with standard deviation $\sigma$ of the gaussian curve is given by

$$
H(u, v)=e^{-D^{2}(u, v) / 2 \sigma^{2}}
$$

where $\mathrm{D}(\mathrm{u}, \mathrm{v})$ is the distance between the point $(\mathrm{u}, \mathrm{v})$ in the frequency domain and the center of the frequency rectangle. By letting $\sigma=\mathrm{D}_{0}$ we can express the filter as

$$
H(u, v)=e^{-D^{2}(u, v) / 2 D_{0}^{2}}
$$

Where $\mathrm{D}_{0}$ is the cutoff frequency

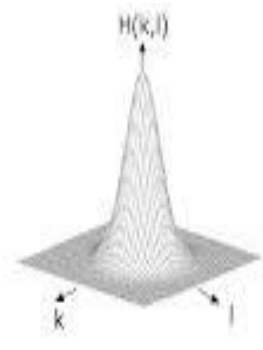

(d)

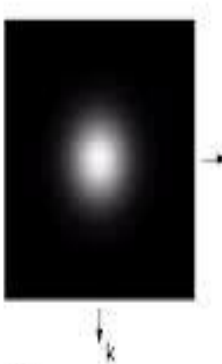

(b)

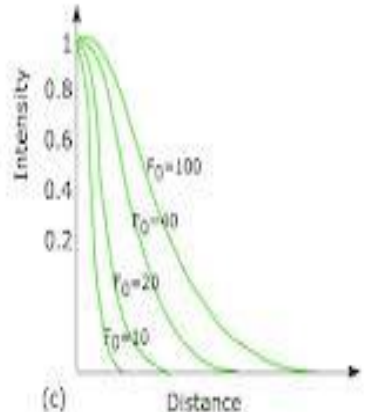

(c)
(a)Perspective plot of an gaussian lowpass filter transfer function (b) Filter displayed as an image. (c) Filter radial cross section.

The Gaussian low pass filter achieved slightly less smoothening than the butterworth low pass filter of order 2 for the same value of cut-off frequency, as can because the profile of Gaussian low pass filter is not as "tight" as the profile of the butterworth low pass filter of order 2 . However, the results are quite comparable, and we are assured of no ringing in the case of the Gaussian low pass filter. This is an important characteristic in practice, especially in situations in which any type of artifact is unacceptable.

\section{Calculating a Gaussian Matrix, also known as a} Kernel

Let's say we wanted to find out how we would weigh neighbouring pixels if we wanted a 'window' or 'kernel size' of 3for our Gaussian blur. Of course the centre pixel (the pixel we are actually blurring) will receive the most weight. Lets choose a $\boldsymbol{\sigma}$ of 1.5 for how blurry we want our image.

Here's what our weight window would look like:

$$
\begin{array}{lll}
\frac{1}{2 \pi 1.5^{2}} e^{-\left(\left(1^{2}+1^{2}\right) / 2 * 1.5^{2}\right)} & \frac{1}{2 \pi 1.5^{2}} e^{-\left(0^{2}+1^{2}\right) / 2 * 1.5^{2}} & \frac{1}{2 \pi 1.5^{2}} e^{-\left(1^{2}+1^{2}\right) / 2 * 1.5^{2}} \\
\frac{1}{2 \pi 1.5^{2}} e^{-\left(1^{2}+0^{2}\right) / 2 * 1.5^{2}} & \frac{1}{2 \pi 1.5^{2}} e^{-(0) / 2 * 1.5^{2}} & \frac{1}{2 \pi 1.5^{2}} e^{-\left(1^{2}+0^{2}\right) / 2 * 1.5^{2}} \\
\frac{1}{2 \pi 1.5^{2}} e^{-\left(1^{2}+1^{2}\right) / 2 * 1.5^{2}} & \frac{1}{2 \pi 1.5^{2}} e^{-\left(0^{2}+1^{2}\right) / 2 * 1.5^{2}} & \frac{1}{2 \pi 1.5^{2}} e^{-\left(1^{2}+1^{2}\right) / 2 * 1.5^{2}}
\end{array}
$$


With each weighting evaluated it looks like this: (Notice that the weighting for the centre pixel is greatest)

\section{Results of Blurring Using a Gaussian Low Pass Filter}

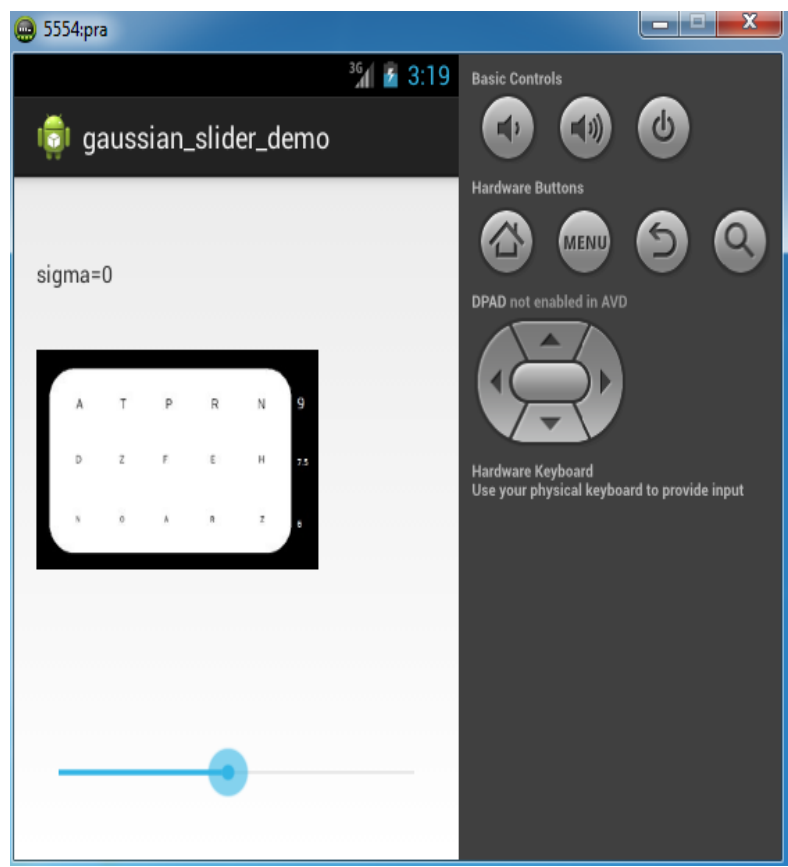

Fig 3.2: Gaussian blurred image for sigma $=0$

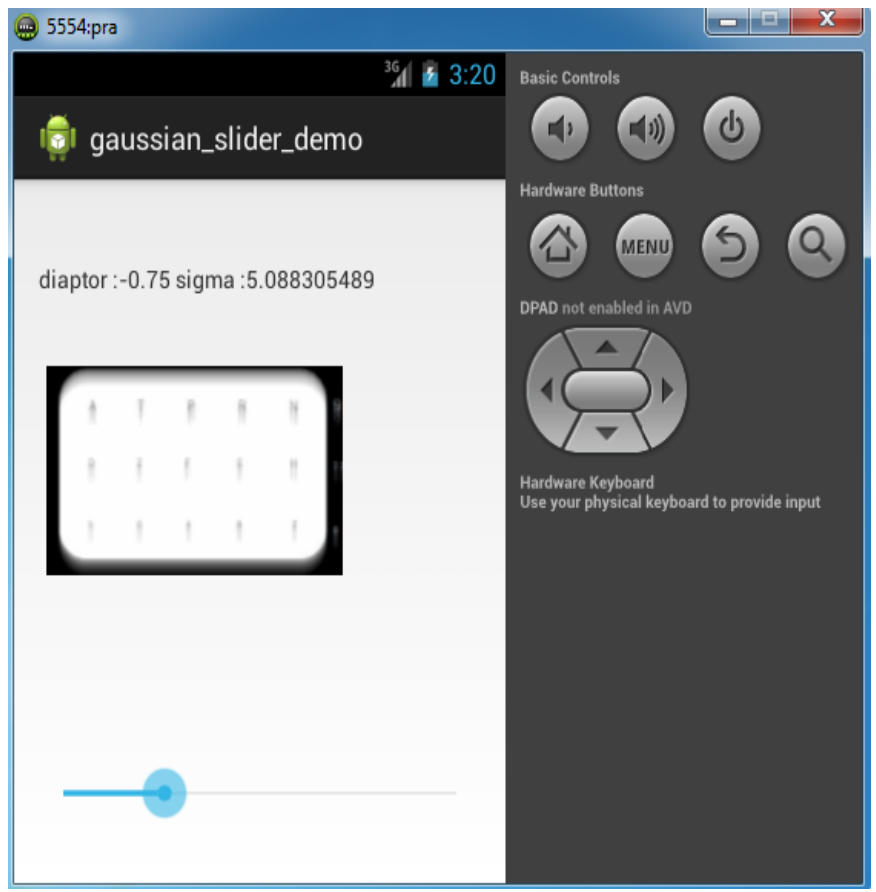

Fig 3.3 Gaussian blurred image for diaptor:-0.75 sigma: 5.088305489
3.3 Comparison of Filters (Gaussian, Butterworth th, Ideal, Median, Mean)

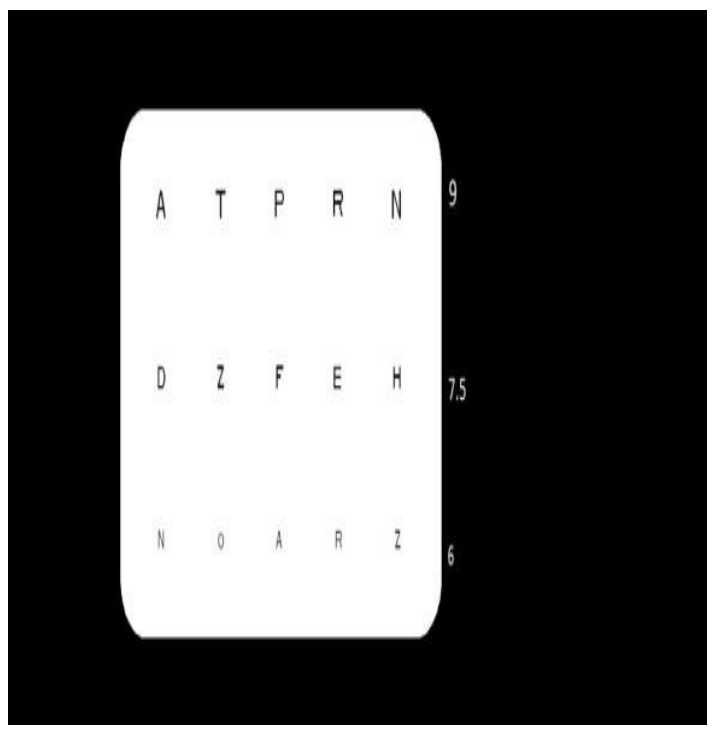

Original image

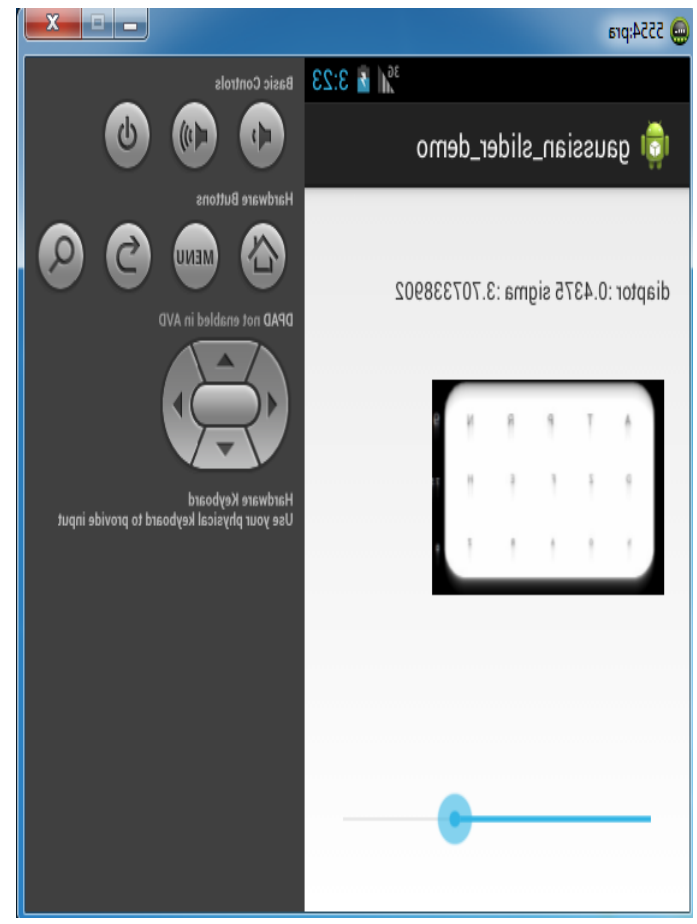

Gaussian Filter blurred image 


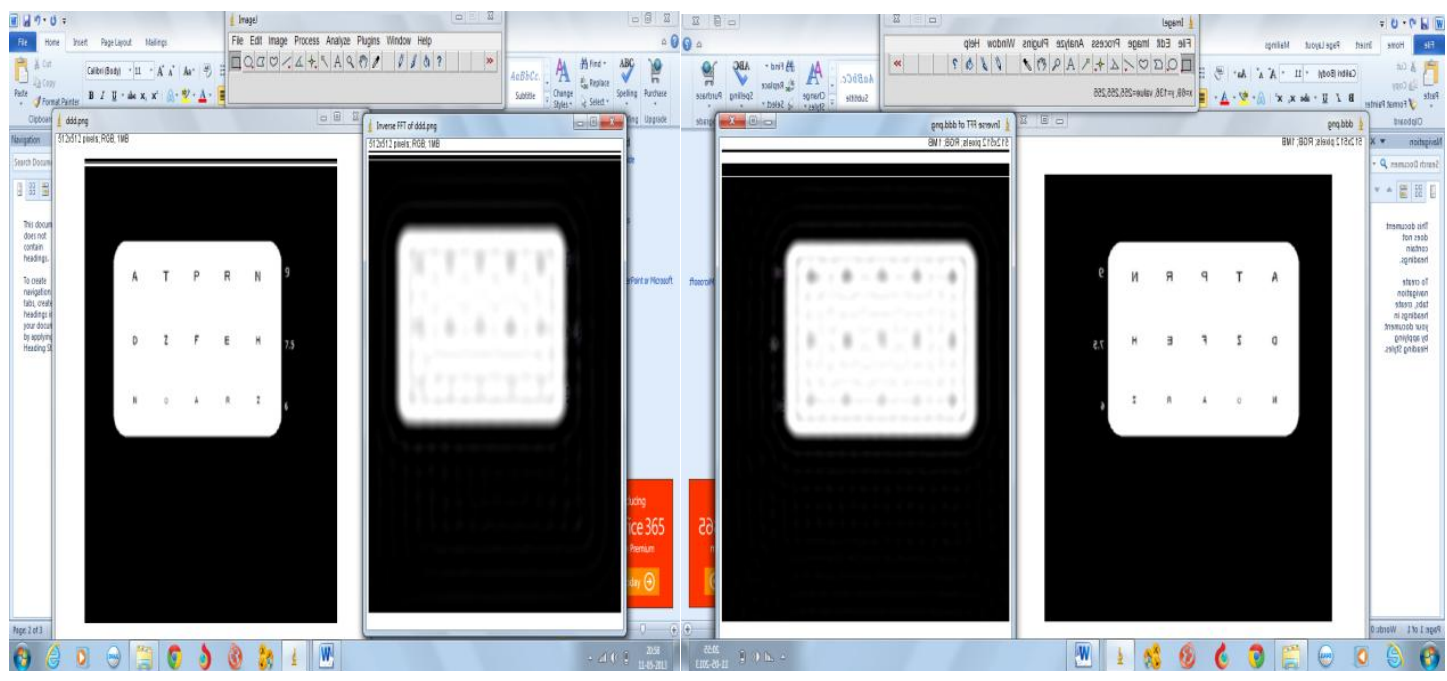

Butter worth filter blurred image

Ideal filter Blurred image

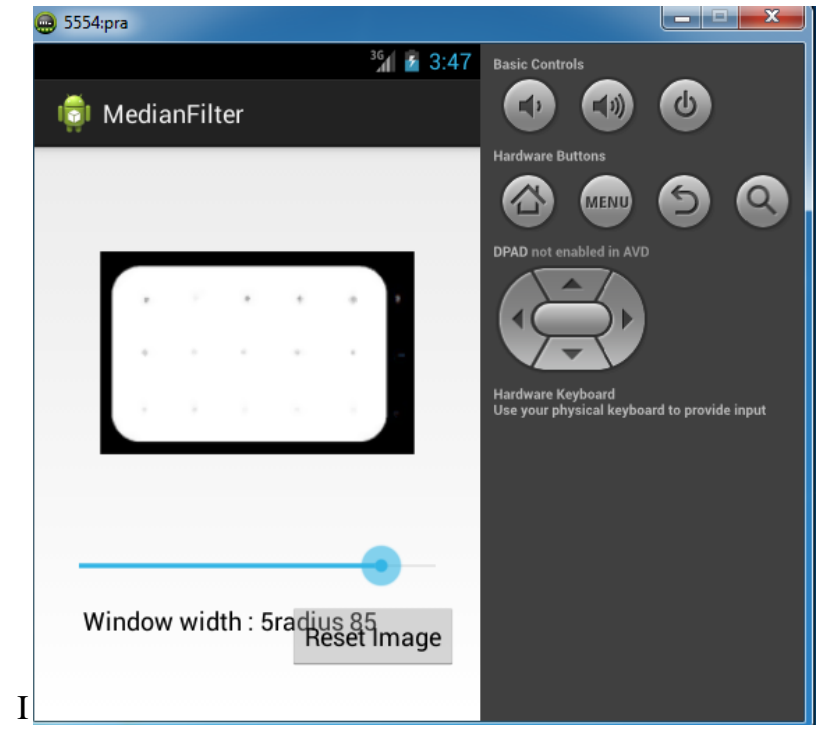

Median Filter blurred image

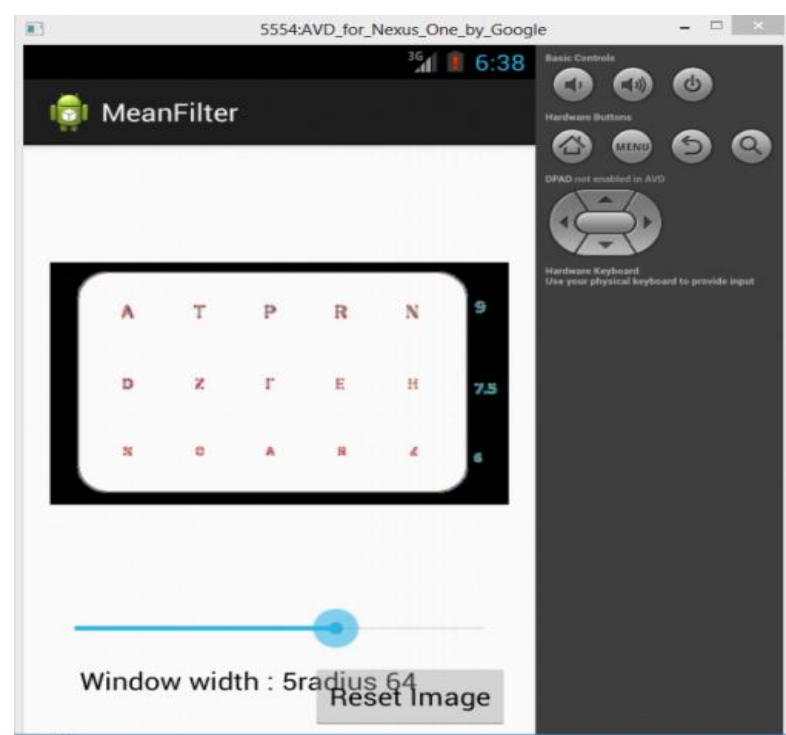

Mean filter blurred image

Fig 3.4 comparison

\subsection{Choosing the Right Lowpass Filter:}

Since among all the filters implemented, Gaussian lowpass filter is more suitable for measuring the human acuity errors, because Gaussian low pass filter has a standard deviation " $\sigma$ " in its denominator which is responsible for blurring an image in an efficient manner. By varying the " $\sigma$ " in small amounts, blurring the image in very smooth way without distortion of the elements present in an image is possible.

That is why, Gaussian low pass filter is chosen so that the sigma value could be helpful to relate it with the dioptre value.
The dioptre values for sigma values are as follows:

Table 3.1 sigma-dioptre values

\begin{tabular}{|l|l|}
\hline Dioptre & Sigma \\
\hline-2 & 14.05578759 \\
\hline-1.9375 & 13.64856802 \\
\hline-1.875 & 13.14289976 \\
\hline-1.8125 & 12.72285203 \\
\hline-1.75 & 12.24850835 \\
\hline-1.6875 & 11.81533413 \\
\hline-1.625 & 11.37589499 \\
\hline
\end{tabular}




\begin{tabular}{|c|c|}
\hline-1.5625 & 10.92959427 \\
\hline-1.5 & 10.47702864 \\
\hline-1.4375 & 10.01760143 \\
\hline-1.375 & 9.551312649 \\
\hline-1.3125 & 9.130966587 \\
\hline-1.25 & 8.704952267 \\
\hline-1.1875 & 8.218973747 \\
\hline-1.125 & 7.781026253 \\
\hline-1.0625 & 7.337112172 \\
\hline-1 & 6.887231504 \\
\hline-0.9375 & 6.431384248 \\
\hline-0.875 & 5.969570406 \\
\hline-0.8125 & 5.560859189 \\
\hline-0.75 & 5.088305489 \\
\hline-0.6875 & 4.670346062 \\
\hline-0.625 & 4.187947494 \\
\hline-0.5625 & 3.762231504 \\
\hline-0.5 & 3.333830549 \\
\hline-0.4375 & 2.904534606 \\
\hline-0.375 & 2.476431981 \\
\hline-0.3125 & 2.054295943 \\
\hline-0.25 & 1.64826969 \\
\hline-0.1875 & 1.32875895 \\
\hline-0.125 & 1.0325179 \\
\hline-0.0625 & 1.01625895 \\
\hline 0 & 1 \\
\hline 0.625 & 1.290274463 \\
\hline 0.125 & 1.626491647 \\
\hline 0.1875 & 2.00477327 \\
\hline 0.25 & 2.408412888 \\
\hline 0.3125 & 2.829355609 \\
\hline 0.375 & 3.263126492 \\
\hline 0.4375 & 3.707338902 \\
\hline 0.5 & 4.160501193 \\
\hline 0.5625 & 4.622016706 \\
\hline 0.625 & 5.012529833 \\
\hline 0.6875 & 5.488066826 \\
\hline 0.75 & 5.970763723 \\
\hline 0.8125 & 6.378878282 \\
\hline 0.875 & 6.874701671 \\
\hline 0.9375 & 7.293556086 \\
\hline 1 & 7.802505967 \\
\hline 1.0625 & 8.145883055 \\
\hline 1.125 & 8.66676611 \\
\hline 1.1875 & 9.01849642 \\
\hline 1.25 & 9.551610979 \\
\hline 1.3125 & 10.00178998 \\
\hline 1.375 & 10.4573389 \\
\hline 1.4375 & 10.91825776 \\
\hline 1.5 & 11.38424821 \\
\hline 1.5625 & 11.85590692 \\
\hline
\end{tabular}

\begin{tabular}{|l|l|}
\hline 1.625 & 12.33323389 \\
\hline 1.6875 & 12.71927208 \\
\hline 1.75 & 13.20674224 \\
\hline 1.8125 & 13.700179 \\
\hline 1.875 & 14.09934368 \\
\hline 1.9375 & 14.50208831 \\
\hline 2 & 15.01103819 \\
\hline & \\
\hline & \\
\hline
\end{tabular}

\section{4 .1 Testing}

\section{For Gaussian Low Pass Filter}

\begin{tabular}{|l|l|l|l|l|l|l|}
\hline $\begin{array}{l}\text { Te } \\
\text { st } \\
\text { id }\end{array}$ & $\begin{array}{l}\text { Test } \\
\text { case } \\
\text { nam } \\
\text { e }\end{array}$ & $\begin{array}{l}\text { Test } \\
\text { case } \\
\text { descript } \\
\text { ion }\end{array}$ & $\begin{array}{l}\text { Expect } \\
\text { ed } \\
\text { output }\end{array}$ & $\begin{array}{l}\text { Obser } \\
\text { ved } \\
\text { output }\end{array}$ & $\begin{array}{l}\text { Sta } \\
\text {-tus }\end{array}$ & $\begin{array}{l}\text { com } \\
\text { ment } \\
\text { s }\end{array}$ \\
\hline 01 & $\begin{array}{l}\text { And } \\
\text { ro- } \\
\text { id } \\
\text { ima } \\
\text { ge }\end{array}$ & $\begin{array}{l}\text { Image } \\
\text { should } \\
\text { be } \\
\text { display } \\
\text { ed on } \\
\text { android } \\
\text { emulato } \\
\text { r }\end{array}$ & $\begin{array}{l}\text { Image } \\
\text { should } \\
\text { be } \\
\text { displa } \\
\text { yed } \\
\text { on } \\
\text { androi } \\
\text { d } \\
\text { emulat } \\
\text { or }\end{array}$ & $\begin{array}{l}\text { Image } \\
\text { is } \\
\text { displa }\end{array}$ & $\begin{array}{l}\text { Pas } \\
\text { s }\end{array}$ & $\begin{array}{l}\text { Displ } \\
\text { aying } \\
\text { imag } \\
\text { e on } \\
\text { emul } \\
\text { ator } \\
\text { is } \\
\text { done }\end{array}$ \\
& & & & \\
\end{tabular}

\begin{tabular}{|c|c|c|c|c|c|c|}
\hline $\begin{array}{l}\text { Te } \\
\text { st } \\
\text { id }\end{array}$ & $\begin{array}{l}\text { Test } \\
\text { case } \\
\text { nam } \\
\mathrm{e}\end{array}$ & $\begin{array}{l}\text { Test } \\
\text { case } \\
\text { descript } \\
\text { ion }\end{array}$ & $\begin{array}{l}\text { Expect } \\
\text { ed } \\
\text { output }\end{array}$ & $\begin{array}{l}\text { Obser } \\
\text { ved } \\
\text { output }\end{array}$ & $\begin{array}{l}\text { Sta } \\
\text { tus }\end{array}$ & $\begin{array}{l}\text { com } \\
\text { ment } \\
\mathrm{s}\end{array}$ \\
\hline 02 & $\begin{array}{l}\text { Gau } \\
\text { ssia } \\
\mathrm{n} \\
\text { blur }\end{array}$ & $\begin{array}{l}\text { Image } \\
\text { should } \\
\text { be } \\
\text { blurred } \\
\text { using } \\
\text { GLPF }\end{array}$ & $\begin{array}{l}\text { Image } \\
\text { should } \\
\text { be } \\
\text { blurre } \\
\text { d }\end{array}$ & $\begin{array}{l}\text { Image } \\
\text { is } \\
\text { blurre } \\
\text { d }\end{array}$ & $\begin{array}{l}\text { Pas } \\
\text { s }\end{array}$ & $\begin{array}{l}\text { Blurr } \\
\text { ing of } \\
\text { an } \\
\text { imag } \\
\text { e } \\
\text { using } \\
\text { GLP } \\
\text { F is } \\
\text { done }\end{array}$ \\
\hline
\end{tabular}

\begin{tabular}{|c|c|c|c|c|c|c|}
\hline $\begin{array}{l}\mathrm{Te} \\
\text { st } \\
\text { id }\end{array}$ & $\begin{array}{l}\text { Test } \\
\text { case } \\
\text { nam } \\
\mathrm{e}\end{array}$ & $\begin{array}{l}\text { Test } \\
\text { case } \\
\text { descript } \\
\text { ion } \\
\end{array}$ & $\begin{array}{l}\text { Expect } \\
\text { ed } \\
\text { output }\end{array}$ & $\begin{array}{l}\text { Obser } \\
\text { ved } \\
\text { output }\end{array}$ & $\begin{array}{l}\text { Sta } \\
\text { tus }\end{array}$ & $\begin{array}{l}\text { com } \\
\text { ment } \\
\mathrm{s}\end{array}$ \\
\hline 03 & $\begin{array}{l}\text { GLP } \\
\text { F } \\
\text { with } \\
\text { sigm } \\
\text { a } \\
\text { incr } \\
\text { eme } \\
\text { nts }\end{array}$ & $\begin{array}{l}\text { Image } \\
\text { should } \\
\text { be } \\
\text { blurred } \\
\text { with } \\
\text { given } \\
\text { increme } \\
\text { nts }\end{array}$ & $\begin{array}{l}\text { When } \\
\text { slider } \\
\text { is } \\
\text { moved } \\
\text { image } \\
\text { should } \\
\text { be } \\
\text { blurre }\end{array}$ & $\begin{array}{l}\text { Image } \\
\text { is } \\
\text { getting } \\
\text { blur in } \\
\text { increm } \\
\text { en-ts } \\
\text { while } \\
\text { slider }\end{array}$ & $\begin{array}{l}\text { Pas } \\
\text { S }\end{array}$ & $\begin{array}{l}\text { GLP } \\
\mathrm{F} \\
\text { with } \\
\text { sigm } \\
\text { a } \\
\text { Incre } \\
\text { ment- } \\
\text { s }\end{array}$ \\
\hline
\end{tabular}




\begin{tabular}{|c|c|c|c|c|c|c|}
\hline & $\begin{array}{l}\text { usin } \\
\text { g } \\
\text { slide } \\
\text { r }\end{array}$ & & $\begin{array}{l}\mathrm{d} \quad \text { in } \\
\text { given } \\
\text { increm } \\
\text { en } \\
\text {-ts }\end{array}$ & $\begin{array}{l}\text { is } \\
\text { movin } \\
\mathrm{g}\end{array}$ & & $\begin{array}{l}\text { using } \\
\text { slider } \\
\text { is } \\
\text { done }\end{array}$ \\
\hline $\begin{array}{l}\mathrm{Te} \\
\text { st } \\
\text { id }\end{array}$ & $\begin{array}{l}\text { Test } \\
\text { case } \\
\text { nam } \\
\mathrm{e} \\
\end{array}$ & $\begin{array}{l}\text { Test } \\
\text { case } \\
\text { descript } \\
\text { ion }\end{array}$ & $\begin{array}{l}\text { Expect } \\
\text { ed } \\
\text { output }\end{array}$ & $\begin{array}{l}\text { Observ } \\
\text { ed } \\
\text { output }\end{array}$ & $\begin{array}{l}\text { St } \\
\text { at } \\
\text { us }\end{array}$ & $\begin{array}{l}\text { com } \\
\text { ment } \\
\mathrm{s}\end{array}$ \\
\hline 04 & $\begin{array}{l}\text { Judg } \\
\text { ing } \\
\text { the } \\
\text { type } \\
\text { of } \\
\text { blurr } \\
\text { ness } \\
\text { in } \\
\text { GLP } \\
\text { F }\end{array}$ & $\begin{array}{l}\text { The } \\
\text { blurring } \\
\text { should } \\
\text { not } \\
\text { distort } \\
\text { the } \\
\text { compon } \\
\text { ents of } \\
\text { image } \\
\text { not it } \\
\text { should } \\
\text { not } \\
\text { create } \\
\text { any } \\
\text { disturba } \\
\text { nces } \\
\text { b/w } \\
\text { letters } \\
\text { nor it } \\
\text { should } \\
\text { not } \\
\text { override } \\
\text { the } \\
\text { borders }\end{array}$ & $\begin{array}{l}\text { When } \\
\text { Gaussi } \\
\text { an blur } \\
\text { is } \\
\text { applied } \\
\text { distorti } \\
\text { on of } \\
\text { compo } \\
\text { nents , } \\
\text { disturb } \\
\text { ance } \\
\text { B/w } \\
\text { letters } \\
\text { and } \\
\text { overrid } \\
\text { ing of } \\
\text { border } \\
\mathrm{s} \\
\text { should } \\
\text { not } \\
\text { happen }\end{array}$ & $\begin{array}{l}\text { No } \\
\text { distorti } \\
\text { on of } \\
\text { compo } \\
\text { nents , } \\
\text { disturb } \\
\text { ance } \\
\mathrm{B} / \mathrm{w} \\
\text { letters } \\
\text { and } \\
\text { overrid } \\
\text { ing of } \\
\text { border } \\
\mathrm{s}\end{array}$ & $\begin{array}{l}\mathrm{Pa} \\
\mathrm{SS}\end{array}$ & $\begin{array}{l}\text { Type } \\
\text { of } \\
\text { blur } \\
\text { is } \\
\text { judg } \\
\text { ed }\end{array}$ \\
\hline
\end{tabular}

\section{RESULTS}

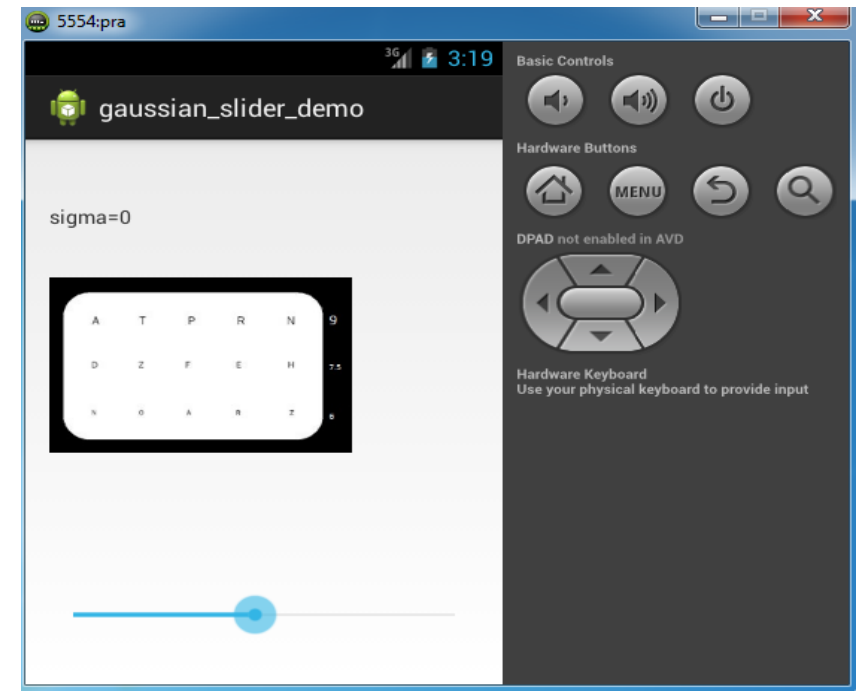

Fig 4.1: Screen shot of the application

\section{CONCLUSIONS}

In this project, first, using the digital image processing concepts we simulated three filters namely, ideal low pass filter, Butterworth filter and Gaussian filter in Matlab. After observing the pattern of blurring, Gaussian filter blurring better suited to the blur which a human eye can visualize. Next, we developed an android application that will be deployed on the tablet-PC, which helps the doctor in finding out the accurate visual acuity errors of human eye. In this application the image is blurred in different magnitudes and is presented to the patient. For the purpose of blurring we used Gaussian filter.

In the future, an application can be developed so as to replace the use of auto-refractometer completely in finding the visual acuity errors of the human eye.

\section{REFERENCES}

[1]. Digital Image Processing,3rd Edition by Rafael C. Gonzalez, Richard E.Woods

[2]. The Unified Modeling Language User Guide, The $2^{\text {nd }}$ Edition by Grady Booch, James Rumbaugh, Ivar Jacobson

[3]. Guillaume Franç ois, Pascal Gautron, Gaspard Breton, and Kadi Bouatouch, "Image-Based Modeling of the Human Eye" IEEE Transaction on visualizations and computer Graphics volume no 15 september/October 2009.

[4]. Michael S.Bittermann, I.sevil sariylidiz, ozer ciftcioglu, "Blur in Human vision and Increased visual realism in virtual environments".

[5]. Michael F.Deering "A Photon Accurate Model of Human Eye" October 2, 2005.

[6]. J. Zuo and N.A. Schmid, "A Model Based, Anatomy Based Method for Synthesizing Iris Images," Advances in Biometrics, vol. 3832, pp. 428435, 2005.

[7]. Atchison, and smith, g. Optics of the Human Eye. Butterworth- Heinemann January 2000.

[8]

http://developer.android.com/training/basics/firstapp/index.ht $\mathrm{ml}$

[9]

http://docs.opencv.org/doc/tutorials/introduction/android_bina ry_package/ O4A_SDK.html

[10]. http://docs.opencv.org/modules/core/doc/intro.html [11]

http://docs.opencv.org/modules/imgproc/doc/filtering.html?hi ghlight= gaussianblur\#gaussianblur

[12]. http://en.wikipedia.org/wiki/Eyeglass_prescription

[13]. http://en.wikipedia.org/wiki/Myopia

[14]. http://en.wikipedia.org/wiki/Hypermetropia

[15].http://www.rohto.co.uk/index.php?option=com_content\& view $=$ article $\&$ id $=69 \&$ Itemid $=37$

[16]. https://www.youtube.com/watch?v=DPLBPdux6bs 


\section{BIOGRAPHIES}

V.Punna Rao, working as Assistant professor in Vasavi college of Engineering, Ibrahimbag, Hyderabad. He did undergraduate study in Computer Science and Engineering from the Institution of Electronics and Telecom Engineers(IETE), New Delhi, following Graduated from Indian Institute of Technology Kharagpur(IIT Kgp). He is working on several consultancy and $\mathrm{R}$ and $\mathrm{D}$ projects. His areas of interest are image processing, algorithms design and computer networks and protocols.

Prof. T. Adilakshmi, Head of the department CSE, Vasavi College of Engineering, Ibrahimbag, Hyderabad. She did undergraduate in Electronics and Communication Engineering from the Vasavi College of Engineering, Hyderabad and following Graduated from Manipal Institute of Technology, Karnataka, and P.hd from Hyderabad Central University(HCU), Guiding several UG,PG, and Phd projects. Published a dozen papers in national and international journals and conferences

Anugar Pradan, M.tech in Computer Science and engineering student from Vasavi college of Engineering. 